\title{
Becoming a Teacher in Italy Today. The Origins of Current Paths.
}

\author{
Simona Savelli \\ Università degli studi Guglielmo Marconi \\ Roma, Italia
}

\begin{abstract}
Bearing in mind the recent law of comprehensive reform of the Education and Training System, this paper summarizes the origin and development of specific paths devoted to the professional training of Teachers who want to work in Italian Public Schools. A comparison between the United States and the Italian contexts offers a starting point for subsequent analysis. Hence, they are described the essential features of the Education and Training Courses dedicated to teaching in Italian public Schools of various levels and grades. Following the development of regulation, I address issues such as: the role of initial training and internship, the ways of achieving licensures/certifications, the mechanism that regulates public competitions for permanent positions, the formation of rankings and the introduction to the teaching function. The paper concludes with an overview of the levels of governance provided by the Integrated Education and Training System that the government intends to implement in the coming years.
\end{abstract}

Keywords: Teachers' Training; Italian Education and Training System; Vocational Training; Teacher's professional profile; Concorso.

\section{Introduction}

At present, the Italian education and training system is undergoing a new wave of reforms. Actually, changes never cease to happen, making it difficult to take a picture of the existing situation every time. I have been addressing this issue recently, first of all considering the political-institutional role of the National State and of the Regioni (Savelli, 2014a). Similarly, in the same period, I took an interest in the United States Education and Training System and in another short essay I investigated the role played by the Federal State and Federated States in that context (Savelli, 2015). In both cases then, I examined the internal systems' articulation. The following table presents a comparison of the two (Table 1)1.

1The table was compiled by updating the information drawn from: Savelli, 2014b; Savelli, 2016; D.L. 59/2004; D.M. 254/2012; D.L. 226/2005; D.P.C.M. 25 gennaio 2008; D.P.R. 89/2010. In this text, normative acts are cited, indicating, in order (where applicable): type of act, act number, (date or) year of publication. Among the types of normative acts mentioned: Legge (L.) (Law); Decreto Legge (D.L.) (Decree Law); Decreto Legislativo (D.Lgs) 
This framework is intended to be a starting point and a major point of reference in addressing the subject covered by this paper: the training path that needs to be undertaken by those who want to become teachers in Italy today.

Table 1. Italian and US Education and Training Systems in comparison.

\begin{tabular}{|c|c|c|c|c|}
\hline $\begin{array}{l}\text { Education } \\
\text { Levels }\end{array}$ & & ITALY & \multicolumn{2}{|l|}{ UNITED STATES } \\
\hline & \multicolumn{2}{|c|}{ Scuola dell'Infanzia (Asilo Nido, Scuola Materna) } & $\begin{array}{l}\text { Pre-Kindergarten, } \\
\text { Kindergarten (Nursery } \\
\text { School) }\end{array}$ & \multirow{4}{*}{$\mathrm{PK}-12$} \\
\hline $\begin{array}{l}\text { Istruzione } \\
\text { Primaria/ } \\
\text { Primary } \\
\text { Education }\end{array}$ & \multirow{2}{*}{$\begin{array}{l}\text { Primo } \\
\text { ciclo di } \\
\text { istruzione }\end{array}$} & Scuola Primaria (Scuola Elementare) & $\begin{array}{l}\text { Primary School (Elementary } \\
\text { School) }\end{array}$ & \\
\hline \multirow[b]{2}{*}{$\begin{array}{l}\text { Istruzione } \\
\text { Secondaria/ } \\
\text { Secondary } \\
\text { Education }\end{array}$} & & $\begin{array}{l}\text { Scuola Secondaria di primo grado (Scuola } \\
\text { Media) }\end{array}$ & $\begin{array}{l}\text { Junior High School (Middle } \\
\text { School) }\end{array}$ & \\
\hline & $\begin{array}{l}\text { Secondo } \\
\text { ciclo di } \\
\text { istruzione }\end{array}$ & $\begin{array}{l}\text { Scuola Secondaria di secondo grado (Scuola } \\
\text { Superiore): } \\
\text { - Istruzione secondaria superiore (liceo } \\
\text { artistico, liceo classico, liceo linguistico, } \\
\text { liceo musicale e coreutico, liceo scientifico, } \\
\text { liceo delle scienze umane). } \\
\text { - Istruzione e formazione professionale: } \\
\text { percorsi di istruzione e formazione } \\
\text { professionale. }\end{array}$ & $\begin{array}{l}\text { Senior High School (High } \\
\text { school) }\end{array}$ & \\
\hline \multirow{3}{*}{$\begin{array}{l}\text { Istruzione } \\
\text { Terziaria)/ } \\
\text { Tertiary } \\
\text { Education }\end{array}$} & \multicolumn{2}{|c|}{$\begin{array}{l}\text { Istituti Tecnici Superiori (percorsi di istruzione e } \\
\text { formazione tecnica superiore). }\end{array}$} & \multicolumn{2}{|c|}{$\begin{array}{l}\text { Postsecondary Career and Technical } \\
\text { Schools (Vocational Education and } \\
\text { Private Career Training). }\end{array}$} \\
\hline & \multirow{2}{*}{\multicolumn{2}{|c|}{$\begin{array}{l}\text { Universita (corsi di laurea, corsi di laurea magistrale, } \\
\text { corsi di specializzazione, corsi di dottorato di ricerca). }\end{array}$}} & \multicolumn{2}{|l|}{ Colleges (of different kinds). } \\
\hline & & & \multicolumn{2}{|l|}{ Universities } \\
\hline
\end{tabular}

\section{Education and training paths for school teaching}

In the 1990s, a specific graduate course with two programs of study provides for the cultural and professional training of Nursery and Elementary School teachers $^{2}$ (L. 341/1990). The Bachelor's Degrees in Primary Education ${ }^{3}$ are required to be admitted to the related concorsi ${ }^{4}$ for teaching positions in the two school levels. The concorsi have a funzione abilitante 5 .

The degree course is placed in the Faculty of Education ${ }^{6}$ and lasts four years, two of which are a common biennium. The activities are both theoretical-formal and theoretical-practical with didactic and teaching workshops. The minimum

(Legislative Decree); Decreto del Presidente del Consiglio dei Ministri (D.P.C.M.) (Prime Ministerial Decree); Decreto del Presidente della Repubblica (D.P.R.) (Presidential Decree); Decreto Ministeriale (D.M.) (Ministerial Decree); Decreto Interministeriale (D.I.) (Interministerial Decree); Decreto Direttoriale (D.D.) (Directorial Decree). For what concerns the internal structure of normative acts: articolo (art.) (first level sub-division) is article (American English), comma (second level sub-division) refers to paragraph, the third level is indicated by lettera (letter) Normative acts have also Allegati and Tabelle (Annexes and Tables).

${ }^{2}$ Today, Scuola dell'infanzia (Kindergarten) and Scuola Primaria (Primary School).

${ }^{3}$ Diplomi di Laurea in Scienze della Formazione Primaria, SFP.

${ }^{4}$ The italian concorsi can be can be defined synthetically as open competitive examinations for state level employment. The word comes from the latin concurrsu(m), to run together. The text will further clarify their operation in the field of Education.

${ }^{5}$ The funzione abilitante can be literally translated with 'qualifying function' and can be assimilated to the teacher's licensure/certification. This last topic is addressed in the paper mentioned in (Savelli, 2015).

${ }^{6}$ Facoltà di Scienze della Formazione. Following the reorganization legislation (particularly law L.240/2010), the University system is starting to formalize the suppression of Faculties in favor of Research Departments (Dipartimenti di Ricerca) and Specialization Schools (Scuole di Specializzazione). However, they are not expressly prohibited by current legislation. 
total commitment is 2000 hours, of which 400 are of supervised practice ${ }^{7}$. Supervised student teaching is held from the third year under the guidance of a teacher or of the Instructional Director and is regulated by a convention between the University and the School Authority. The supervisor expresses an evaluation of the student's activity, which, if negative, involves repetition.

The required study plans include:

- at least one semester module in: the Legal Area; the Socio-Anthropological Area; the Area of Music and Sound Communication; the Area of Drawing;

- at least the equivalent of an annuality in: the Environmental, Natural and Hygienic Sciences Area; the Historical-Social Area;

- two annualities in: the Linguistic-Literary Area; the Pedagogical Area; the Methodological-Didactic Area.

For the Methodological-Didactic, the Linguistic-Literary and the PhysicalMathematical Areas is compulsory to pass at least one Didactic examination.

The Nursery Program of Study is oriented to the Expressive-Artistic Communication, Motoring and Socialization Areas. The Elementary School Program of Study is oriented to the Literary, the Mathematical-Scientific and the Modern Language Teaching Areas.

To be admitted to the graduation examination, the student must have passed all the tests prescribed in the required study plan, a verification test on foreign language knowledge and must complete the internship ${ }^{8}$. The graduation examination consists in discussing a dissertation and a report on the internship activity.

In the same period, the Graduate School for Secondary School Teachers ${ }^{9}$ is established. The School is structured in two programs of study and provides for the training of secondary school teachers, also through guided activities. The number of people enrolled is established annually (D.P.R. 470/1996). The course lasts two years and includes a minimum of 700 hours of teaching and 300 hours of guided student teaching entrusted to Permanent Secondary School Teachers ${ }^{10}$. The required study plans include:

- at least 5 semesters in Education Sciences common to students of all programs of study;

- at least 5 semesters in Disciplinary Didactics corresponding to the abilitazioni ${ }^{11}$ to achieve.

The School Board develops a study plan for each student that takes into account his curriculum and the abilitazioni he intends to attain. At the conclusion of the course the student prepares a report on his teaching activity that is evaluated during the final examination. In accordance with the diplomas that have given access to the Graduate School, the Diplomas awarded allow access to the concorsi for the related teaching positions in Secondary Schools (D.P.R. 470/1996). In 2010, in the turbulent succession of reforms, a new decree (D.M.

\footnotetext{
7Tirocinio didattico.

${ }^{8}$ Tirocinio.

${ }^{9}$ Scuola di specializzazione per gli insegnanti della scuola secondaria, SSIS.

10Insegnanti di ruolo.

11The term abilitazione (plural: abilitazioni) has the meaning of licensure and certification. It certifies that a teacher is able to teach and that he has the legal possibility to do so. For this reason I decided to use the italian term throughout the text.
} 
249/2010) was issued to specifically regulate the necessary requirements and modalities for the initial training of teachers of Kindergarten, Primary and Junior and Senior High Schools.

So, it is established that initial training of teachers involves the acquisition of Disciplinary, Methodological-Didactic, Organizational and Relational competences and skills necessary for the development and support of the autonomy of school institutions ${ }^{12}$.

For teaching in Kindergarten and Primary Schools the training path involves attending a Master's degree course lasting five years, in a single cycle, with supervised student teaching starting from the second year of the course.

For teaching in Junior and Senior High Schools, the training path involves the attendance of a biennial Master's Degree course and the subsequent completion of one year of Supervised Active Practice ${ }^{13}$.

They are an integral part of the training paths the acquisition of: English language skills of B2 level14, digital competences ${ }^{15}$, Didactics skills to facilitate the integration of pupils with disabilities (L.104/1992).

\subsection{Paths for teaching in Kindergartens and Primary Schools}

The Master's Degree program for teaching in Kindergarten and Primary School ${ }^{16}$ is typically activated at the Faculty of Education. In order to be admitted to the course is required to hold a Senior High School Diploma and pass an access test. The degree program aims to provide solid knowledge in the various discipline fields subject matter of teaching, to train to manage the classroom and to plan the education and teaching path, in addition to the knowledge and skills needed to tackle school integration of children with special needs. Therefore, beside most disciplines, they are provided one or more Pedagogical-Didactic Workshops enabling students to experiment personally the practical transposition of what they learned in the classroom. Starting from the second year, they are carried out supervised indirect activities of preparation, reflection, discussion and documentation and supervised direct activities in schools. These activities develop over 600 hours, equivalent to 24 College Credit Hours ${ }^{17}$ and they expand gradually from the second year of the course to the fifth, ending with a report. Student teaching is followed by Teacher Tutors and coordinated by Tutor Coordinators and Tutor Organizers. It provides observation activities, work activities in guided situations and activities where the student is fully autonomous. The degree thesis focuses on disciplinary topics related to teaching, which may be related to the internship.

\footnotetext{
12This is the premise of the development of the staff of autonomy prescribed by law L. 107/2015.

13 Tirocinio Formativo Attivo, TFA.

${ }^{14}$ Provided for by the Common European Framework of Reference for Languages adopted in 1996 by the Council of Europe.

${ }^{15}$ Provided for by the Recommendation of the European Parliament and of the Council of 18 December 2006.

${ }^{16}$ Corso di laurea magistrale per l'insegnamento nella scuola dell'infanzia e nella scuola primaria, class LM-85 bis.

${ }^{17}$ Crediti Formativi Universitari, CFU. The major difference between the U.S. College Credit System and the European Credit System is that the first is based on contact hours and the second on student workload (Retrieved from: http://www.mastersportal.eu/articles/1110/what-you-need-to-know-about-academic-credit-systems-in-the-us.html). This distinction is also true for the italian system. One credit corresponds to a minimum of 25 hours of work per student. The average amount of academic work done in one year for a student engaged in full-time University Studies is conventionally fixed at 60 credits (Savelli, 2014a).
} 
At the end of the path, the graduates of each degree class ${ }^{18}$ get their abilitazione to teach in Primary Schools. The achievement of the certification is the result of an overall assessment of the study curriculum, the degree thesis and the internship report by a Committee consisting of University teachers supplemented by two tutors and a ministerial representative nominated by the Regional School Offices ${ }^{19}$.

The profile of graduates includes knowledge of specific elements in the disciplines of Mathematics, Physics, Chemistry, Biology, Italian Literature, Italian Language, English Language, History, Motor Activity, Art, Music, Childhood Literatures, Pedagogy, Special Pedagogy, Experimental Pedagogy, Psychology, Sociology, Anthropology, Law, Infantile Neuropsychiatry, Clinical Psychology, General and Applied Hygiene. In teaching the disciplines they are taken into account the two school levels for which the course qualifies.

\subsection{Paths for teaching in Junior and Senior High Schools}

Training paths for teaching in Junior High Schools include: the achievement of the restricted access Master's degrees; the successful completion of the TFA, including the examination having the value of abilitazione.

For each class of abilitazione, they are defined the requirements for access the test and the Master's Degree needed to access the tirocinio (D.M. 249/2010).

The proposed table (Table 2) has explanatory purposes and intends to clarify the mechanism underlying the operation of the entire system ${ }^{20}$.

Similarly, training courses for teaching in Senior High Schools include the achievement of the restricted access Master's Degree; the development of the TFA including the abilitazione examination (D.M. 249/2010).

The 2010 decree regulates the tirocinio for Junior and Senior High Schools teachers. This is a training course for teaching reserved for those who have completed the restricted access Master's Degree above-mentioned. Upon completion of the supervised active practice (TFA), after passing the final examination, they are achieved the abilitazioni to teach in Junior and Senior High Schools, in one of the abilitazione classes prescribed by the MIUR (D.M. 37/2009; D.M. 39/1998).

The decree mentioned above, amended and supplemented by a subsequent decree of 2013 (D.M. 81/2013), regulates the access test to TFA courses. This is a test aimed at verifying the disciplinary knowledge in the subject matters of teaching of the abilitazione classes. The test is structured in a preliminary national test, a written test and an oral examination. In addition to the study path and the average of the examinations of the Master's Degree and the Master's Degree thesis, within the boundaries of each abilitazione class, further points can be attributed to: the Ph.D; the service provided in the institutions of the National

\footnotetext{
${ }^{18}$ Classe di laurea.

${ }^{19}$ The Regional School Offices (Uffici Scolastici Regionali, USR) are established by a decree of 2000 (D.P.R. 347/2000) and disciplined by a Decree of 2007 (D.P.R. 260/2007). They replace the previous Provveditorati agli Studi.

${ }^{20}$ For Junior High Schools, the table synthesizes the abilitazione that can be achieved (a) after having obtained the Academic Degree in the corresponding Class (d) performing the required Study Program (b) (c) and after having carried out the TFA. The degree class indicated is the compulsory class degree required to gain access to the tirocinio. For each of these degree classes, the legislation indicates the mandatory CFUs that must be achieved for each scientific-disciplinary sector. It also indicates and disciplines the CFUs related to workshops, internships and practical activities.
} 
Education Service; the scientific research activity carried out; publications or other qualifications.

Table 2. Required certifications for teaching in Junior High Schools.

\begin{tabular}{|c|c|c|c|c|c|}
\hline $\begin{array}{c}\text { Licensure/Certification } \\
\text { Class (a) }\end{array}$ & & CFU Area (b) & & CFU Sector (c) & Degree Class (d) \\
\hline \multirow[t]{5}{*}{$\begin{array}{l}\text { Italian, History and } \\
\text { Geography in First } \\
\text { Grade Secondary School } \\
\text { (A043). }\end{array}$} & \multirow[t]{5}{*}{102} & \multirow{5}{*}{$\begin{array}{l}\text { Historical Area; } \\
\text { Philological-Literary } \\
\text { Area; Artistic Area; } \\
\text { Linguistics Area; } \\
\text { Philosophical Area; } \\
\text { Geographical Area; } \\
\text { Pedagogical Area; } \\
\text { Psychological Area; } \\
\text { Area of Political } \\
\text { Science. }\end{array}$} & 18 & $\begin{array}{l}\text { Italian Literature, } \\
\text { Contemporary Italian } \\
\text { Literature (of which at } \\
\text { least } 12 \text { in the first). }\end{array}$ & \multirow[t]{5}{*}{$\begin{array}{l}\text { Modern Philology } \\
\text { (LM-14). }\end{array}$} \\
\hline & & & 18 & $\begin{array}{l}\text { Medieval history; } \\
\text { Modern History; } \\
\text { Contemporary History. }\end{array}$ & \\
\hline & & & 12 & $\begin{array}{l}\text { Italian Languistics; } \\
\text { Glottology and } \\
\text { Linguistics. }\end{array}$ & \\
\hline & & & 9 & $\begin{array}{l}\text { Latin Language and } \\
\text { Literature. }\end{array}$ & \\
\hline & & & 9 & Geography. & \\
\hline \multirow{6}{*}{$\begin{array}{l}\text { English Language and } \\
\text { Second Foreign } \\
\text { Language (A045). }\end{array}$} & \multirow[t]{6}{*}{66} & \multirow{6}{*}{$\begin{array}{l}\text { Linguistics Area; } \\
\text { Philological-Literary } \\
\text { Area. }\end{array}$} & 18 & English Language. & \multirow{6}{*}{$\begin{array}{l}\text { Foreign Language } \\
\text { (LM-37). }\end{array}$} \\
\hline & & & 12 & $\begin{array}{l}\text { Second Community } \\
\text { Language. }\end{array}$ & \\
\hline & & & 12 & English Literature. & \\
\hline & & & 12 & $\begin{array}{l}\text { Literature of The } \\
\text { Second Community } \\
\text { Language. }\end{array}$ & \\
\hline & & & 6 & $\begin{array}{l}\text { Italian Literature; } \\
\text { Contemporary Italian } \\
\text { Literature; Literary } \\
\text { Criticism and } \\
\text { Comparative } \\
\text { Literature. }\end{array}$ & \\
\hline & & & 6 & $\begin{array}{l}\text { Glottology and } \\
\text { Linguistics; Didactics } \\
\text { of Modern Languages; } \\
\text { Italian Linguistics. }\end{array}$ & \\
\hline \multirow{4}{*}{$\begin{array}{l}\text { Mathematics And } \\
\text { Science in First Grade } \\
\text { Secondary School } \\
\text { (A059). }\end{array}$} & \multirow[t]{4}{*}{132} & \multirow{4}{*}{$\begin{array}{l}\text { Mathematics Area; } \\
\text { Physics Area; } \\
\text { Chemistry Area; } \\
\text { Geology Area; } \\
\text { Biology Area; } \\
\text { Computer Science } \\
\text { Area; Computer } \\
\text { Engineering Area. }\end{array}$} & 12 & $\begin{array}{l}\text { Mathematics (from } \\
\text { MAT 01 to MAT 09). }\end{array}$ & \multirow{4}{*}{$\begin{array}{l}\text { Mathematical, } \\
\text { Chemical, Physical and } \\
\text { Natural Sciences in } \\
\text { First Grade Secondary } \\
\text { School (LM-95). }\end{array}$} \\
\hline & & & 6 & $\begin{array}{l}\text { Physics (from FIS } 01 \\
\text { to FIS 07). }\end{array}$ & \\
\hline & & & 6 & $\begin{array}{l}\text { Chemistry (from } \\
\text { CHIM } 01 \text { to CHIM 12; } \\
\text { from GEO } 01 \text { to GEO } \\
09 \text {; from BIO } 01 \text { to } \\
\text { BIO 19). }\end{array}$ & \\
\hline & & & 6 & $\begin{array}{l}\text { Computer Science; } \\
\text { Information Processing } \\
\text { Systems; Statistics. }\end{array}$ & \\
\hline \multirow[t]{4}{*}{$\begin{array}{l}\text { Motor Science and } \\
\text { Sports (A030). }\end{array}$} & \multirow[t]{4}{*}{120} & \multirow{4}{*}{$\begin{array}{l}\text { Motor and Sport } \\
\text { Area; Biomedical } \\
\text { Area; Sociological } \\
\text { Area; Psychological } \\
\text { Area; Pedagogical } \\
\text { Area. }\end{array}$} & 24 & $\begin{array}{l}\text { Methods and Didactics } \\
\text { of Motor Activities. }\end{array}$ & \multirow{4}{*}{$\begin{array}{l}\text { Science of Motor And } \\
\text { Sports Activities (L- } \\
\text { 22); Diploma Awarded } \\
\text { by the Istituto } \\
\text { Superiore di } \\
\text { Educazione Fisica } \\
\text { (ISEF) (Higher } \\
\text { Institute of Physical } \\
\text { Education); Science } \\
\text { and Techniques of } \\
\text { Preventive and } \\
\text { Adapted Motor } \\
\text { Activities (LM-67); } \\
\text { Science and } \\
\text { Techniques of Sport } \\
\text { (LM-68). }\end{array}$} \\
\hline & & & 12 & $\begin{array}{l}\text { Methods and Didactics } \\
\text { of Sports Activities. }\end{array}$ & \\
\hline & & & 18 & $\begin{array}{l}\text { Biomedical Area (BIO } \\
09,10,16 ; \text { MED 09, } \\
13,33,38,39 \text { ). }\end{array}$ & \\
\hline & & & 18 & $\begin{array}{l}\text { Sociological, } \\
\text { Psychological, } \\
\text { Pedagogical Area (M- } \\
\text { PED 02, 03, 04; M-PSI } \\
\text { 04, 05, SPS 08). }\end{array}$ & \\
\hline
\end{tabular}




\begin{tabular}{|c|c|c|c|c|c|}
\hline \multirow[t]{8}{*}{ Music (A032). } & \multirow[t]{8}{*}{72} & \multirow{8}{*}{$\begin{array}{l}\text { Historical Area; } \\
\text { Philological-Literary } \\
\text { Area; Area of the } \\
\text { Sciences of } \\
\text { Antiquity; Artistic } \\
\text { Area; Linguistics } \\
\text { Area; Demo-Ethno- } \\
\text { Anthropological } \\
\text { Area; Philosophical } \\
\text { Area; Geographical } \\
\text { Area; Pedagogical } \\
\text { Area; Psychological } \\
\text { Area; Sociological } \\
\text { Area. }\end{array}$} & 12 & L-ART from 01 to 06 & \multirow{8}{*}{$\begin{array}{l}\text { Musicology and } \\
\text { Musical Goods (LM- } \\
\text { 45). }\end{array}$} \\
\hline & & & \multirow{7}{*}{6} & at least 2 of: & \\
\hline & & & & $\begin{array}{l}\text { Musicological Area } \\
\text { (L-ART 07, L-ART } \\
\text { 08). }\end{array}$ & \\
\hline & & & & $\begin{array}{l}\text { Literary Area (L-FIL- } \\
\text { LET from } 10 \text { to } 12 ; \text { L- } \\
\text { LIN 01, 03, 05, 05, } 10 \text {, } \\
11,13 \text { ). }\end{array}$ & \\
\hline & & & & $\begin{array}{l}\text { Philosophical Area } \\
\text { (M-FIL from } 01 \text { to } 08 \text { ). }\end{array}$ & \\
\hline & & & & $\begin{array}{l}\text { Historical Area (L- } \\
\text { ANT 02, 03, M-STO } \\
01,02,04 \text { ). }\end{array}$ & \\
\hline & & & & $\begin{array}{l}\text { Psycho-Pedagogical } \\
\text { Area (M-PED 01, M- } \\
\text { PSI 01, M-DEA 01). }\end{array}$ & \\
\hline & & & & $\begin{array}{l}\text { Artistic Area (L-ART } \\
\text { from } 01 \text { to } 06 \text { ). }\end{array}$ & \\
\hline \multirow[t]{9}{*}{ Technology (A033). } & \multirow[t]{9}{*}{90} & \multirow{9}{*}{$\begin{array}{l}\text { Mathematics Area; } \\
\text { Computer Science } \\
\text { Area; Physics Area; } \\
\text { Chemistry Area; } \\
\text { Geology Area; } \\
\text { Industrial } \\
\text { Engineering Area; } \\
\text { Computer } \\
\text { Engineering Area; } \\
\text { Statistics Area. }\end{array}$} & 6 & $\begin{array}{l}\text { from MAT } 01 \text { to MAT } \\
08 .\end{array}$ & \multirow{9}{*}{$\begin{array}{l}\text { Technology in First } \\
\text { Grade Secondary } \\
\text { School (LM-96). }\end{array}$} \\
\hline & & & 6 & MAT 09; INF 01. & \\
\hline & & & 6 & $\begin{array}{l}\text { FIS 01, 02, 04,05, 06, } \\
08 \text {; CHIM 01,02,03, } \\
06,08,10,12 .\end{array}$ & \\
\hline & & & 6 & FIS 03, 04, 07 & \\
\hline & & & 6 & $\begin{array}{l}\text { CHIM 04, 05, 07, 09, } \\
11 .\end{array}$ & \\
\hline & & & 6 & $\begin{array}{l}\text { Civil Engineering Area } \\
\text { (ICAR from } 01 \text { to } 13 \text {, } \\
\text { ICAR } 16,17,20 \text { ). }\end{array}$ & \\
\hline & & & 12 & $\begin{array}{l}\text { Industrial Engineering } \\
\text { Area (INGIND from } \\
01 \text { to } 35 \text { ). }\end{array}$ & \\
\hline & & & 12 & $\begin{array}{l}\text { Computer Engineering } \\
\text { Area (INGINF from } 01 \\
\text { to 07). }\end{array}$ & \\
\hline & & & 18 & $\begin{array}{l}\text { M-PED 01, 02, 03, M- } \\
\text { PSI 04, 05, M-DEA } 1 \\
\text { (of which } 6 \text { in M-ped } \\
01 \text { or M-PED 02). }\end{array}$ & \\
\hline
\end{tabular}

The preliminary test consists of closed-ended questions with four options. The questions are of different types, including questions to verify language skills and the understanding of texts. To be admitted to the written test, the candidate must have a minimum grade. The written test, prepared by Universities, consists of open-ended questions on the subject matters of teaching in the related concorso classes (D.M. 249/2010). To be admitted to the oral examination, the candidate must have a minimum grade and it is passed if the candidate scores a minimum rating. The examination is organized taking into account the specificities of the various degree classes. Succeeding in the oral examination is an indispensable condition for accessing the TFA.

The ranking of the candidates admitted to the TFA is formed by adding the scores obtained in the preliminary test, the written test, and the oral examination with the score attributed to qualifications.

Tests programs are defined annually by MIUR decrees. The following table (Table 3) refers to their discipline for a.y. 2014/2015. 
Table 3. Discipline of test programs for a.y. 2014/2015 (D.M. 312/2014).

\begin{tabular}{|l|l|}
\hline \multicolumn{1}{|c|}{ TEST TYPE } & \multicolumn{1}{c|}{ VERIFICATION ELEMENTS } \\
\hline Preliminary test (1) & $\begin{array}{l}\text { Disciplinary knowledge on the subject matters of teaching of cach abilitazione class. } \\
\text { Linguistic skills required in the area of competence in Italian. }\end{array}$ \\
\hline Written test (2) & $\begin{array}{l}\text { One or more of the disciplines included in the concorso class to which the TFA Arefers. } \\
\text { Discipline knowledge; ability to analyze, interpret and argue; correct use of the Italian language } \\
\text { (does not include closed-ended questions). } \\
\text { Foreign Language concorso classes; in foreign language. } \\
\text { Italian Language concorso classes: text analysis. } \\
\text { Classical Languages concorso classes: translation test. } \\
\text { Scientific or Technical Disciplines concorso classes: possible integration of laboratory practical } \\
\text { test. }\end{array}$ \\
\hline Oral examination & $\begin{array}{l}\text { Specificity of different concorso classes. } \\
\text { Concorso classes for Foreign Language: in forcign language. }\end{array}$ \\
\hline
\end{tabular}

The TFA has an annual duration and correspond to 60 CFUs. It is set up at a Faculty where all the activities take place, but can also be realized in collaboration by several Faculties.

The Internship Training Council21 curates the integration of activities, organizes didactic-disciplinary workshops and establishes the forms of collaboration among Trainees Tutors, Tutor Coordinators and University Professors.

Those who obtain the abilitazione in the TFA courses: acquire solid knowledge of the subjects matters of teaching and have the ability to propose them in the most appropriate way to the school level of the students they come in contact with; they are able to manage the progression of learning by adapting times and modes to the class, choosing time after time the tools most suited to the considered path; posses Pedagogical, Didactic, Relational and Managerial abilities; have the ability to work with broad autonomy also by taking organizational responsibilities.

In order to achieve these objectives, the TFA path includes: Education Sciences teachings, with particular emphasis on Didactic Methodologies and Special Needs; Disciplinary Didactics teachings that can also be carried out in a laboratory context so as to secure content with teaching methods; an internship of 475 hours equal to 19 CFUs, which involves indirect activities and observation and active teaching at schools, under a tutor's guidance; Pedagogical-Didactic laboratories oriented at re-elaborating and comparing the proposed teaching practices and internship experiences ${ }^{22}$.

The internship activity is concluded by the trainee's writing of a report in collaboration with the Teacher Tutor who followed the activity as CoSupervisor. The Supervisor is a University Professor.

The report highlights the ability to integrate the skills acquired in classroom activities with Psycho-Pedagogical knowledge and the acquired knowledge in Disciplinary Didactics, particularly in workshop activities.

${ }^{21}$ Consiglio di Corso di Tirocinio, CCT. The Internship Training Council consists of: Tutor Coordinators, Teachers and University Researchers that are carrying out teaching assignments in the internship, two School Principals or Instructional Coordinators designated by the USR among the School Principals or Instructional coordinators that host the Internships and a Representative of trainee students. The President of the Council is elected by University Professors, his term lasts three years and is renewable only once.

${ }^{22}$ Compulsory attendance is required for: $70 \%$ of Education Sciences lessons, $80 \%$ of tirocinio, $70 \%$ of Disciplinary Didactics lessons, $70 \%$ of Pedagogical and Didactic workshops. 
At the end of the course is evaluated the activity carried out, the oral presentation of a didactic path on a topic selected by the examination committee ${ }^{23}$, the discussion of the final report. A minimum total grade is necessary to pass the examination. To the score obtained is added the score resulting from the weighted average of the grades of the final examinations of each discipline of the Master's Degree and of the examinations taken during the year of internship. The total score expressed as a percentage is the grade of the abilitazione for teaching.

At the end of the path, the students will award the qualification required for teaching in one of the concorso classes prescribed by the MIUR (D.M. 39/1998; D.M. 22/2005).

\section{Recruitment of the teaching staff}

In 1994 the recruitment of the teaching staff takes place at provincial level through a concorso ${ }^{24}$. Here I am going to provide an idea of the complex mechanism underlying it and the legacy it has left to our day.

The concorsi can be based on qualifications and examinations or based only on qualifications (D.LGS 297/1994). Access to permanent positions takes place for $50 \%$ by the first type of concorso and for $50 \%$ by the second type of concorso (D.Lgs 297/1994). The Ministry of Public Education ${ }^{25}$ calls the concorsi on the basis of the actual availability of chairs ${ }^{26}$ or of teaching positions in the threeyear reference period, the Provveditorati agli Studi ${ }^{27}$ curate their implementation.

Concorsi based on qualifications and examinations consist of one or more written tests, of an oral examination and of the evaluation of qualifications. In addition, it is assessed the abilitazione for the concorso classes for which it is prescribed. Each written test consists of an articulated discussion of cultural and professional issues. The oral examination is intended to ensure that future teachers are prepared on educational and didactic issues, contents of teaching programs and ordinamenti scolastici ${ }^{28}$. A minimum grade is required to pass the test.

The sum of the scores in the written test (or tests), the oral examination and the evaluation of qualifications forms the merit ranking, valid for the three years

\footnotetext{
${ }^{23}$ The Examination Board consists of three University Professors who conducted the activities of tirocinio, two Tutor Coordinators, one Representative appointed by the USR. The Board is chaired by a Professor appointed by the Faculty of reference.

${ }^{24}$ In 1994 the consolidated law in Education is published. This is a decree law (D.Lgs 297/1994) consisting of 676 articles, which regulates the entire school system. With its modifications and integrations it still constitutes a normative reference point in this area.

${ }^{25}$ Ministero della pubblica istruzione (MPI). This Ministry is instituted in 1989. The current configuration of the Ministry of Education, University and Research (Ministero dell'istruzione, dell'università e della ricerca, MIUR) is established for the first time in 1999 and then, after various events, is restored in 2008.

${ }^{26}$ Cattedre.

${ }^{27}$ The Provveditorato agli Studi is a peripheral office of the MPI from which Nursery, Elementary and Secondary Teachers, Inspectors, School Directors and Instructional Directors are dependent. The Provveditorati agli Studi are established in 1859 and abolished in 2000 (D.P.R. 347/2000).

28 The ordinamenti didattici scolastici discipline school operation in a way similar to how the ordinamenti didattici universitari discipline universities. The ordinamenti didattici universitari discipline: the list of subjects that constitute each course of study, the specific learning objectives and related credits, the set of learning activities considered for the achievement of the qualification and the rules for the submission of the individual curricula, the regulations regarding the possible compulsory attendance (Savelli, 2014a).
} 
indicated in the concorso notices ${ }^{29}$. They are nominated the candidates that are placed in a convenient position in relation to the number of chairs or posts available.

They are admitted to the concorsi based on qualifications ${ }^{30}$ those who have passed a previous concorso based on qualifications and examinations for the same concorso class or the same position and who have provided teaching services in State Institutes and Schools of every level and grade for at least 360 days in the previous three years ${ }^{31}$.

A Legislative Decree of 1994 defines these last 'permanent rankings': competitors already included in them, but not yet nominated, have the right to remain in the ranking and to obtain a change of score by the evaluation of new qualifications (D.Lgs. 297/1994).

Subsequently, by a Law of 1999 (L. 124/1999) it is established that:

- if a merit ranking runs out of the assigned positions, these are to be added to those of the corresponding permanent ranking;

- permanent rankings are integrated by teachers requesting the transfer from the corresponding permanent ranking of another district (provincia) and, in order of priority, by:

- $\quad$ staff meeting the requirements for participation in the concorsi for qualifications only (the suppressed concorsi) (L. 124/1999; D.L. 255/2001), this is called 'first batch'32;

- teachers who have passed the tests of a previous concorso based on qualifications and examinations in relation to the same concorso class and the same position (D.L. 255/2001), this is called 'second' or 'last batch' 33 .

- Starting from the school year (s.y.) 2004/2005, the rankings of the last batch are restated:

- a specific number of points are awarded for passing a concorso based on qualifications and examinations or for achieving the abilitazione as a result of the attendance of the SISS or for the degree in Primary Education valid for accessing the Nursery and Elementary Schools rankings;

- a specific number of points are awarded for the teaching service provided in schools starting from s.y. 2003/2004 (L. 97/2004; D.L. 236/2004).

In 2004, a new decree legally establishes that starting from the a.y. 2005/2006, the non-application for permanence entails the cancellation from the permanent ranking and that, since 2004 the abilitazione from the SISS is a qualifying entry only for the purpose of inclusion in the last batch of permanent rankings (D.L. 97/2004).

\footnotetext{
${ }^{29}$ Bandi di concorso.

30The concorsi based on qualifications (but not the related rankings) are suppressed by the law L. 124 /1999.

31The subject matter of teaching must correspond to the permanent position, it must be done on the basis of the qualification required to access the position, for teachings related to the concorso classes (D.Lgs. 297/1994).

${ }^{32}$ Primo scaglione.

${ }^{33}$ Secondo or ultimo scaglione. For further details on this matter please see the transitional rules of the law L. $124 / 1999$ and the authentic interpretation rules of the D.L. 255/2001.
} 
Then, by law of 2006, permanent rankings are transformed in until exhaustion rankings ${ }^{34}$ (L. 296/2006).

\section{The Good School Reform}

In 2015 a new reform of the National Education and Training System is launched and a reorganization of existing legislation is provided (L. 107/2015) 35 .

In this context, they are defined an extraordinary recruitment plan and the ordinary procedures for accessing permanent positions, as summarized below.

\subsection{Recruitment procedures}

For the s.y. 2015/2016 the MIUR ${ }^{36}$ is authorized to implement an extraordinary plan of recruitment for teaching staff vacant and available posts after the operations of the introduction to permanent positions for the same s.y.. After these operations, the rankings for the concorsi based on qualifications and examinations called before 2012 are suppressed.

In addition, the Ministry is authorized to cover curriculum enhancement positions for the achievement of national priority targets ${ }^{37}$ and for up to ten days substitute teaching, in accordance with the educational needs expressed by institutions. These positions may not be covered by the staff holding a contract for short-term substitute teaching and since s.y. 2016/2017, flow into the Autonomy Staff 38 .

Thus, they are employed permanently for the above mentioned posts:

- those entered in the rankings of the public concorso based on qualifications and examinations for permanent positions called in 2012 (D.D. 82/2012) for the recruitment of the teaching staff for State Schools of every level and grade;

- those listed on the teaching staff until exhaustion rankings.

- At the same time, an extraordinary plan for territorial and professional mobility of teachers employed permanently is undertaken within the s.y. $2014 / 2015$ on all vacancies of the autonomy staff, derogating from the three-year restriction of stay in the provincia (D.Lgs 297/1994; L. 107/2015).

The Autonomy Staff is set up in order to fully implement the process of fulfilment of autonomy and reorganization of the entire Education System. Determined on a regional basis every three-years, it is functional to the didactic,

\footnotetext{
${ }^{34}$ Graduatorie ad esaurimento.

${ }^{35}$ The L. 107/2015 is also known as La Buona Scuola (The Good School). This is the last law of comprehensive reform of the school system. It consists of 212 articles.

${ }^{36}$ Please, see note 25.

${ }^{37}$ Curriculum enhancement positions are aimed at: enhancing Language skills; enhancing Mathematical-Logical and Scientific skills: enhancing skills in Music, Art, Cinema, Images and Sounds; developing skills in Active and Democratic Citizenship and strengthening Legal and Economic-Financial knowledge; developing responsible behaviors; making literate on Art and Images; developing Motor disciplines; developing of workshops methodologies and activities; preventing and counteracting school dispersion, discrimination, bullying and enhancing inclusion; enhancing of schools as active communities; afternoon opening and the reduction in the number of pupils and students per class; increasing structured work-integrated learning in the Second Cycle of Education; enhancing individualized training paths; identifying functional paths to rewarding and recognition of performance; making literate and perfectionate on Italian as a Second Language; defining a guidance system (L. 107/2015).

${ }^{38}$ Organico dell'autonomia.
} 
organizational and design needs that emerge from the Three-Year Curriculum Plan ${ }^{39}$ of each single school. Thereby School Institutions identify permanent positions needs in relation to the Educational Offer they intend to realize ${ }^{40}$.

The Curriculum Plan constitutes the cultural and design identity of each school institution: it clarifies the curricular, extracurricular ${ }^{41}$, educational and organizational design adopted and contains the training activities programming addressed to the teaching staff. Teachers contribute to its realization with teaching, enhancement, support ${ }^{42}$, organization, design and coordination.

The Curriculum Plan is consistent with the General and Educational Objectives of the different types and programs of study and takes into account the territorial programming of the Educational Offer, which reflects the needs of the Cultural, Social and Economic context of the local reality. It indicates the teachings and disciplines that cover the needs of common, support ${ }^{43}$ and enhancement posts ${ }^{44}$.

Therefore, this last Law of reform establishes that access to permanent positions by the State Schools' teaching staff occurs through concorsi based on qualifications and examinations (L. 107/2015). The determination of positions to allocate for the concorso takes into account the needs expressed by the School Institutions in the Three-Year Training Plans. These concorsi are national, called on a regional basis every three years, for all positions vacant and available, within the limits of financial resources and places available in the three-year period. The relative rankings are valid for three years.

Those who conveniently place themselves in the merit rankings are employed within the limits of the positions allocated. They are the addressees of assignment proposals and express, according to the ranking order, the preference for the local level ${ }^{45}$ within the regione for which they have competed.

Starting from the public concorso for teachers' permanent positions recruitment called in 2015, they can access the concorso procedures based on qualifications and examinations only candidates who hold the abilitazione for teaching.

Starting from s.y. 2016/2017, the School Principal proposes the appointment to permanent teachers assigned to the local level of reference, also taking into account the applications submitted by the teachers themselves and formulates

\footnotetext{
${ }^{39}$ Piano Triennale dell'Offerta Formativa, PTOF.

${ }^{40}$ Within the limits of the available resources, respecting the teachers' timetable, taking into account the autonomy of curricula and flexibility spaces, referring to curriculum enhancement initiatives and planning activities and for the achievement of some priority goals (L. 107/2015; D.P.R. 81/2009).

${ }^{41}$ On the meaning and evolution of the concept of curricolo in the italian context (in italian), please see: Cerini G., Saperi, curricolo, competenze. Fonti, indicazioni normative, materiali. Retrieved from: http://www.edscuola.it/archivio/riformeonline/saperi.html.

${ }^{42}$ The word sostegno, meaning literally 'support', is often used to indicate a special education teacher: insegnante $d i$ sostegno (support teacher).

43Please, see note 27.

44 The distribution of staff numbers among the regions occurs: for common positions, according to the number of classes; for curriculum enhancement positions, according to the number of pupils. Coverage of vacant and available posts has priority, but they are also considered the needs related to projects of particular Educational relevance and projects of National value. To meet further staffing requests, a further quota of posts is provided annually with MIUR's decree. For the coverage of these positions they draw from the rankings of those who aspire to the stipulation of fixed-term contracts or they employ permanent position staff with measures effective for a school year.

${ }^{45}$ The ambiti territoriali are defined by the USR, as instructed by the MIUR, according to the school population, the proximity of school institutions, the characteristics of the territory (L. 107/2015).
} 
the proposal for a three-year assignment and the possible renewals in accordance with the Three-Year Curriculum Plan. If the teacher accepts, the job is assigned.

\subsection{Training and Trial periods}

The teaching staff is undergoing a Training and Trial Period 46 , which if positively passed, determines the actual placing in permanent positions. To pass this period, the teacher must have a minimum of days of service with a minimum of didactic activity. The evaluation is carried out by the School principal, having heard the opinion of the Evaluation Committee ${ }^{47}$ and on the basis of an investigation by a Teacher Tutor 48 designated by the Principal.

The $\mathrm{PFP}^{49}$ is aimed at verifying the mastery of professional standards of the newly recruited teachers, with reference to the following criteria: correct possession and exercise of Cultural, Disciplinary, Didactic and Methodological competences, with reference to the founding nuclei of knowledge, competence goals and learning targets provided by the existing ordinamenti; correct possession and exercise of Relational, Organizational and Managerial skills; observance of the duties connected with the status of a public employee and inherent the teaching function; participation in training activities and achievement of the objectives set out therein (D.M. 850/2015).

Within the second month of service, the newly recruited teacher traces a preliminary analysis of skills, in the form of a structured self-assessment, with the collaboration of the Teacher Tutor. This allows to outline the points to be strengthened and to develop an in-training project consistent with the accomplished diagnosis.

On the basis of this preliminary analysis, the School Principal and the newly recruited teacher, heard the Teacher Tutor and taking into account the needs of the school, establish a specific Professional Development Agreement ${ }^{50}$. The agreement explains the goals of professional development of Cultural, Disciplinary, Didactic-Methodological and Relational nature to be achieved through training activities, including those activated by the School Institution or by School Networks and the possible use of the resources of the Teacher's Card 51 .

\footnotetext{
${ }^{46}$ Periodo di Formazione e di Prova, PFP.

${ }^{47}$ Comitato per la Valutazione. The School Principal chairs the Committee, which remains in office for three scholastic years and consists of three Teachers of the Educational Institution; two parents' representatives or a student representative and a parent representative; an external component. For further information on this matter (in italian), please see: (MIUR) Ministero dell'Istruzione, dell'Università e della Ricerca, Ufficio Relazioni con il Pubblico, (2012) Organi collegiali della scuola, retrieved from: http://www.istruzione.it/urp/organi_collegiali.shtml.

48 The Teacher Tutor is the person that welcomes the newly recruited in the professional community, encourages participation in the various moments of school collegial life and exerts all forms of listening, counselling and collaboration useful to improve the quality and effectiveness of teaching. He prepares moments of mutual observation in the classroom and can collaborate with the newly recruited in the elaboration, experimentation and validation of teaching resources and learning units (D.M. 850/2015). On the features that the tutor must possess, please see D.M.

49 Please, see note 46.

${ }^{50}$ Patto per lo Sviluppo Professionale, PSP.

${ }^{51}$ Carta del docente. The law L. 107/2015 establishes an electronic card for the upgrading and training of permanent teachers of Educational Institutions of every level and grade. The Card is worth 500 Euros per each school year. For all the uses that the card allows, please see D.P.C.M. 28 novembre 2016.
} 
At the end of the Training and Trial Period, the newly recruited teacher with the supervision of the Teacher Tutor, draws up a new analysis of skills to record the progress on professional expertise, the impact of the Educational actions realized, the further developments to hypothesize.

The training activities are organized in the following four phases, for a total duration of 50 hours: preparatory and final restitution meetings; training workshops, peer to peer and classroom observation, online training.

At least one preparatory training meeting is organized by the local school administration at the local level, aiming at illustrating the general modalities of the training course, the expected professional profile, innovations underway in the school. At least one final meeting is intended to complete an overall evaluation of the training action fulfilled. To the initial and final plenary meetings are usually devoted no more than six hours overall.

Training workshops are planned at the local level, taking into account the analysis of skills and on the basis of the recognition of the resulting training needs. These initiatives are characterized by the adoption of professional exchange laboratory-based methods, action research and re-elaboration and production of teaching sequences and by contents closely related to teaching. Normally these activities are structured in four in person meetings of three hours 52 .

Classroom observation activity is aimed at improving didactic practices and shared reflection on the salient aspects of the teaching action. It focuses on ways of conducting activities and lessons, support pupil motivations, build positive and motivating climates and ways to test learning. The observation sequences, designed and reworked with the Teacher Tutor, are the subject matter of a report by the newly hired. To these activities are devoted at least 12 hours.

Online training of the newly employed teacher lasts 20 hours and consists of: the analysis and reflections on the personal training path; the development of a personal Portfolio that documents the design, implementation and evaluation of teaching activities; the compilation of questionnaires for monitoring the different phases; the free research of study materials, learning resources, dedicated sites, made available 53 .

At the end of the year, the Evaluation proceeds with the expression of opinion on the successful completion of the Period. The teacher takes the interview before the committee that begins with the presentation of the teaching and training activities and the relevant documentation contained in the Professional Portfolio. The tutor presents the emerging results of the investigation on the prearranged training activities, teaching experiences and participation in the school life of the newly hired teacher. The School Principal submits a report that includes the documentation of the training activities, of the tutoring forms and

52It is planned the compilation of documentation and research activities, which is validated by the Workshop Coordinator Teacher. The documentation is included in the Professional Portfolio (D.M. 850/2015).

${ }^{53}$ The Directorate-General for School Staff, taking advantage of the technical structure of the Istituto Nazionale di Documentazione Pedagogica, Innovazione e Ricerca Educativa (INDIRE), coordinates the activities for the implementation and updating of the digital platform that supports newly recruited teachers throughout the Training and Trial Period. The Direzione Generale per il Personale della Scuola (13 Offices) carries out the duties and responsibilities of the Ministry in specific fields. For further details on this matter please see D.P.R. 17/2009. The history of INDIRE can be found on the institutional website at: http://www.indire.it. 
any other information element or evidence useful for the expression of an opinion.

At this point the School Principal can issue a substanciated decision of confirmation or a measure of repetition, indicating the critical elements and the forms of training support and verification of the standards' achievement required for confirmation. In case of a second Training and Trial Period, the teacher's testing for eligibility is entrusted to a Technical Manager, who assumes every useful assessment element and presents a report to the Committee. This second assessment may include recognition of adequacy and confirmation, or lack of recognition of adequacy and no confirmation (D.M. 850/2015).

\section{Initial training for High School teaching in 2017}

In April this year, following the entry into force of the reform act, to which reference has so far been made, a decree ${ }^{54}$ is issued to reorganize, adapt and simplify the system of initial training and access to teacher's permanent positions in High Schools.

The initial training system provides for: (1) a national public concorso called on a regional or interregional basis; (2) a three-year path of initial training, supervised practice and placement in the teaching function (FIT path); (3) a procedure for accessing permanent positions, after passing the training path intermediate and final evaluations (D.Lgs 59/2017).

\subsection{The FIT path}

The FIT path is structured in: (a) a first year aimed to the achievement of the Specialist Degree for teaching in High Schools; (b) a second year of training, supervised practice and initial placement in the teaching function; (c) a third year of training, supervised practice and placement in the teaching function.

The path is realized through a structured collaboration as equals among Schools, Universities and AFAM Institutions ${ }^{55}$ and it finds expression in designing, managing and monitoring through specialized regional collegial bodies.

The FIT path aims to develop and strengthen in future teachers: Cultural, Disciplinary, Didactic and Methodological skills in relation to the founding nuclei of knowledge and the skills goals set for students; the unique skills of teachers' training, especially Pedagogical, Relational, Evaluative, Organizational and Technological, integrated in a balanced manner with Disciplinary Knowledge; the ability to Design Flexible Educational Paths and appropriate to the school context, in order to promote Critical and Informed Learning and student acquisition of Skills; the ability to consciously carry out the tasks related to the Teaching Function and the School Organization.

The FIT path is designed and implemented in coordination with the National Training Plan.

The National Conference on Initial Training and Access to Teacher Profession ${ }^{56}$, established this year, aims to coordinate and monitor the system on the basis of

\footnotetext{
${ }^{54} \mathrm{D}$. Lgs 59/2017. This decree provides for a further definition of the system and procedures in successive MIUR decrees, having heard the opinion of the specific advisory bodies.

55/stituti di formazione artistica, musicale e coreutica, AFAM. Institutes of Artistic, Musical and Coreutic Education.

${ }^{56}$ Conferenza Nazionale per la Formazione Iniziale e l'accesso alla Professione Docente.
} 
an organic framework of the skills of teaching as a profession, to be updated continuously, also in comparison with the main training models and international studies. The Conference is composed as equals of experts coming from the School System and the University System. It has advisory and proactive tasks regarding: organization, operation and programs of the FIT paths, structured in vertical curricula and ordinamenti didattici of the specialist courses. It also monitors the activities and results of the system, promoting possible corrective and improvement actions and proposes initiatives for bridging and harmonizing initial training and in-service training for teachers.

\subsection{Access to the FIT path}

The national concorso based on examinations and qualifications to select candidates for accessing the FIT path on Common Positions and Special Needs Positions in High Schools is published twice a year to cover the posts that are expected to become vacant and available in the third and fourth school years following the one in which the completion of the concorso is expected. Based on merit rankings, the winners of the concorso are admitted to the path in two successive annual batches. They are identified positions related to: Junior and Senior High Schools, also grouped in discipline fields; Technical-Practical Teachers; Special Needs.

The concorso classes are reorganized and updated periodically in order to ensure the consistency among subject matters of teaching, teachers' disciplinary classes of entitlement and degree courses' classes ${ }^{57}$.

It is a qualifying entry to the concorso for teachers' positions the joint possession of: a Master's Degree; 24 CFUs acquired in curricular, supplemental or extra curricular form in Anthropo-Psycho-Pedagogical disciplines and Didactic Methodologies and Technologies, of which at least 6 CFUs in each of three of the following four discipline fields: Pedagogy, Special Pedagogy and Didactics of Inclusion; Psychology; Anthropology; Didactic Methodologies and Technologies.

The concorso involves three examination tests: two nationwide written tests and an oral examination. The first written test aims to evaluate the degree of knowledge and skills of the candidate in a specific discipline chosen by the person concerned among those pertinent to the concorso class. The first test must be passed to access the following test.

The second written test aims to evaluate the level of knowledge and skills of the candidate in the Anthropo-Psycho-Pedagogical disciplines and in Didactic Methodologies and Technologies. Successful completion of the second test is required to access the following test.

The oral examination consists of an interview aimed at assessing the level of knowledge and skills of the candidate in all the disciplines that are part of the concorso class, with particular reference to the disciplines not chosen in the first written test; at verifying the knowledge of a European Foreign Language at least at level B2 of the Common European Framework of Reference for Languages and the possession of basic computer skills.

${ }^{57}$ However, in-service permanent teachers can participate in specific training activities to supplement their preparation in order to teach subject matters in similar disciplinary classes or to modify their own disciplinary class of entitlement or typology of position (D.Lgs 59/2017). 
The candidates who have passed all the tests scheduled enter the merit ranking with a score that is given by the sum of scores recorded in all the tests and the evaluation of qualifications. For each concorso class, the winners in a useful position within the limits of the posts allocated are required to start the related FIT path.

\subsection{The FIT path contract}

The winners of the concorso sign a three year FIT contract with the USR of the chosen local level 58 . The contract provides a gradual placement into the teaching function. The contract holder is required to achieve, at the end of the first year, the Specialist Degree, and during the second and third year, to complete his own professional preparation with further study activities, with direct and indirect supervised activities and with teaching activities.

The Specialist Course is established in agreement with the USR, by Universities, with the involvement of Schools. It requires compulsory attendance with financial burden at the expense of the State. The course corresponds to a total of 60 CFUs. It is structured in: lessons, seminars and workshops for completing the preparation of enrolled students in the field of Didactics of all disciplines pertinent to the class of concorso of Pedagogy, Special Pedagogy and Didactics of Inclusion, Psychology, Assessment and School Legislation; supervised direct activities (at least $10 \mathrm{CFUs}$ ) to be held at the schools of the local level of belonging in the presence of the Class Teacher and under the guidance of the School Tutor; supervised indirect activities (at least 6 CFUs) aimed at the reflective accompaniment/support on the experience gained in the supervised direct activities; optional, additional learning activities aimed at acquiring linguistic skills in the perspective of teaching by Content and Language Integrated Learning (CLIL).

Specialist courses conclude with a final examination that takes into account the results achieved by the FIT contract holder in all the training activities. Successful completion of the final exam leads to the achievement of the Specialist Degree.

The contract is confirmed for the second year provided that the holder has completed the Specialist Degree and for the third year, provided that he has successfully passed the intermediate evaluation at the end of the second year.

In the second and third year of contract, the holder is required to prepare and conduct an Action Research Project under the guidance of the University Tutor and of the Tutor Coordinator and to acquire in the two-year period $15 \mathrm{CFUs}$ related to Didactic Innovation and Experimentation, of which at least 9 in workshops.

On the basis of the assignments made by the School Principal, in the second year the holder carries out short term and occasional substitute teaching not exceeding 15 days in the belonging local level, and in the third year he serves on vacant and available posts. The holders choose the position on the basis of the concorso ranking and within the local level in which they are entered.

58The choice of the local level in the region occurs in order of score and according to the available positions (D.Lgs 59/2017). 
Tirocinio Activities are carried out under the guidance of a School Tutor ${ }^{59}$, a Tutor Coordinator 60 and a University Tutor ${ }^{61}$.

Direct activities are carried out in the School Institutions accredited by the MIUR with the coordination of a Pole School within the local level of reference. It is about observation, analysis, design and subsequent realization of teaching activities and of activities serving the purpose of teaching, realized under the guidance of the University Tutor and in collaboration with the Tutor Coordinator. Indirect activities are carried out in Universities and consist of planning, discussion and reflection on the direct tirocinio, under the guidance of the University Tutor and in collaboration with Tutor Coordinators.

The attendance of tirocinio activities is compulsory.

The final evaluation takes into account the degree of development of professional competence, in relation to the Methodological, Didactic, Design and Relational aspects within the classroom and the School Institution.

The third year of the FIT path is specifically aimed at verifying the teachers' mastery of professional standards and concludes with the final evaluation. This year is not repeatable.

The Final Assessment Board for accessing teachers positions is chaired by the School Principal of the school in which the FIT contract holder has served in the third year. The Board includes the University Teachers engaged in the Specialist Courses, the University Tutor and the Tutor Coordinator of the person concerned, the School Tutor of the third year of the contract.

In the case of a positive final assessment, the contract holder is assigned to the local level in which he served during the third year and he is awarded a threeyear assignment.

\section{Conclusion}

With the law on the Good School and the measures stemming from it, the Government intends to implement a System of Education and Training that can possibly harmonize the training actions undertaken by the individual teacher in the context of the professional and school communities of reference with the training plans of individual School Institutions and the contribution of the National Training Plans.

Starting from the elaboration of the curricula of study and of tirocini for specialization and teaching, the aim is to make sure that Universities and Schools can form real spaces of evolution of professional knowledge and a ground for building training alliances, even in the future perspective of lifelong learning. In this sense, all the training required for professional development of teachers is pondered, designed and implemented in accordance with the initial training. Table 4 below provides an overview of the new organization of the

${ }^{59}$ School Tutors are the teachers of the schools where direct activities are realized and they have the task of coordinating these activities in the School Institution. They participate in the definition of the tirocinio paths and are part of the boards evaluating the third year of the FIT course.

${ }^{60}$ Tutor Coordinators are responsible for the planning, organization and co-ordination of supervised indirect and direct activities in collaboration with the School Tutor and the University Tutor. They participate in the Examination Boards for the intermediate and final evaluations of the FIT path.

61University Tutors are identified by Universities and constitute the University reference for the training activities required in the study plans. In collaboration with Tutor Coordinators, they have the task of integrating lessons and seminars with the workshops and tirocini carried out by the contract holders. 
training system, highlighting the different levels of governance planned (Table 4) (Allegato to the D.M. 797/2016).

Table 4. How training will be organized (Allegato to the D.M. 797/2016)

\begin{tabular}{|l|l|}
\hline \multicolumn{1}{|c|}{ SUBJECTS } & \multicolumn{1}{c|}{ ACTIONS } \\
\hline $\begin{array}{l}\text { Ministero } \\
\text { dell'Istruzione, } \\
\text { dell'Universita e della } \\
\text { Ricerca (MIUR) }\end{array}$ & $\begin{array}{l}\text { Control room for the coordination of training } \\
\text { Definition of the National Training Plans. } \\
\text { Development of quality standards. } \\
\text { Overall monitoring of the training system. }\end{array}$ \\
\hline $\begin{array}{l}\text { Uffici Scolastici } \\
\text { Regionali (USR) }\end{array}$ & $\begin{array}{l}\text { Regional Task Force. } \\
\text { Support to territorial levels. } \\
\text { Territorial monitoring. }\end{array}$ \\
\hline Schools & $\begin{array}{l}\text { Network planning within the territorial levels. } \\
\text { Coordination with other training poles. } \\
\text { Drawing up the Institute's Training Plan. }\end{array}$ \\
\hline Teachers & $\begin{array}{l}\text { Individual expression of training needs through the Professional Development Plan. } \\
\text { Collective expression of training needs within the Collegio dei docenti. } \\
\text { Participation in training. } \\
\text { Evaluation of training. }\end{array}$ \\
\hline
\end{tabular}

\section{References}

Cerini, G.. Saperi, curricolo, competenze. Fonti, indicazioni normative, materiali [Knowledge, curriculum, skills. Sources, normative indications, materials]. http://www.edscuola.it/archivio/riformeonline/saperi.html.

De Angelis, F. \& Giovannini, M.L. (2017). Formazione obbligatoria. istruzioni per i docenti di ruolo, neoassunti e di sostegno [Compulsory training, instructions for tenured, newly hired and special needs teachers]. La Tecnica della Scuola. Il Quotidiano della Scuola On Line, $14^{\text {th }}$ November. https://www.tecnicadellascuola.it/ formazione-obbligatoria-istruzioni-docentiruolo-neoassunti-sostegno.

Frabboni, F. (2009). Professione insegnante. Un concerto a più voci in onore di un mestiere difficile [The teaching profession. A concert with many voices in honor of a difficult vocation.]. FrancoAngeli. https://www.francoangeli.it/Ricerca/Scheda_libro.aspx?ID=17436\&Tipo=Libr $o \&$ strRicercaTesto $=\&$ titolo $=$ professione + insegnante $\% 2 \mathrm{E}+\mathrm{un}+$ concerto $+\mathrm{a}+$ piu $+\mathrm{v}$ oci+in+onore+di+un+mestiere+difficile.

D.I. 10 marzo 1997. Decreto Interministeriale, 10 marzo 1997. http://1.flcgil.stgy.it/files/pdf/20110510/decreto-interministeriale-10-marzo1997-formazione-universitaria-insegnanti-scuola-elementare-e-materna.pdf.

D.L. 255/2001. Decreto Legge, 3 luglio 2001, n. 255. Gazzetta Ufficiale n. 153 del 4 luglio 2001.

http:// www.normattiva.it/atto/caricaDettaglioAtto?atto.dataPubblicazioneGaz zetta=2001-07-

04\&atto.codiceRedazionale $=001 \mathrm{G} 0321 \&$ queryString $=\% 3$ FmeseProvvedimento $\%$ 3D\%26formType\%3Dricerca_semplice\%26numeroArticolo\%3D\%26numeroProv vedimento\%3D255\%26testo\%3D\%26annoProvvedimento\%3D2001\%26giornoPr ovvedimento $\% 3$ D\&currentPage $=1$.

D.L. 59/2004. Decreto Legge, 19 febbraio 2004, n. 59. Gazzetta Ufficiale n. 51, 2 marzo 2004, Supplemento Ordinario, n. 31. http://www.normattiva.it/atto/caricaDettaglioAtto?atto.dataPubblicazioneGaz zetta $=2004-03-$

02\&atto.codiceRedazionale $=004$ G0090\&queryString $=\% 3$ FmeseProvvedimento $\%$ 3D\%26formType \%3Dricerca_semplice\%26numeroArticolo\%3D\%26numeroProv 
vedimento\%3D59\%26testo\%3D\%26annoProvvedimento\%3D2004\%26giornoPro vvedimento\%3D\&currentPage $=1$.

D.L. 97/2004. Decreto Legge,7 aprile 2004, n. 97. Gazzetta Ufficiale n. 88, 15 aprile 2004. http://www.normattiva.it/atto/caricaDettaglioAtto?atto.dataPubblicazioneGaz zetta $=2004-04-$

15\&atto.codiceRedazionale $=004 \mathrm{G} 0125 \&$ queryString $=\% 3$ FmeseProvvedimento $\%$ 3D\%26formType\%3Dricerca_semplice\%26numeroArticolo\%3D\%26numeroProv vedimento\%3D97\%26testo\%3D\%26annoProvvedimento\%3D2004\%26giornoPro vvedimento $\% 3$ D\&currentPage $=1$.

D.L. 226/2005. Decreto Legge, 17 ottobre 2005, n. 226. Gazzetta Ufficiale n. 257, 4 novembre 2005, Supplemento Ordinario, n. 175. http://www.normattiva.it/atto/caricaDettaglioAtto?atto.dataPubblicazioneGaz zetta $=2005-11-$

04\&atto.codiceRedazionale $=005$ G0246\&queryString $=\% 3$ FmeseProvvedimento $\%$ 3D\%26formType\%3Dricerca_semplice\%26numeroArticolo\%3D\%26numeroProv vedimento\%3D226\%26testo\%3D\%26annoProvvedimento\%3D2005\%26giornoPr ovvedimento $\% 3$ D\&currentPage $=1$.

D.L. 244/2016. Decreto Legge, 30 dicembre 2016, n. 244. Gazzetta Ufficiale n. 304, 30 dicembre 2016 http://www.normattiva.it/atto/caricaDettaglioAtto?atto.dataPubblicazioneGaz zetta $=2016-12-$

30\&atto.codiceRedazionale $=16$ G00260\&queryString $=\% 3$ FmeseProvvedimento $\%$ 3D\%26formType\%3Dricerca_semplice\%26numeroArticolo\%3D\%26numeroProv vedimento\%3D244\%26testo\%3D\%26annoProvvedimento\%3D2016\%26giornoPr ovvedimento\%3D\&currentPage $=1$.

D.Lgs 297/1994. Decreto Legislativo, 16 aprile 1994, n. 297. Gazzetta Ufficiale n. 115, 19 maggio 1994, Supplemento Ordinario n. 79. http://www.normattiva.it/atto/caricaDettaglioAtto?atto.dataPubblicazioneGaz zetta=1994-05-

19\&atto.codiceRedazionale $=094$ G0291\&queryString $=\% 3$ FmeseProvvedimento $\%$ 3D\%26formType\%3Dricerca_semplice\%26numeroArticolo\%3D\%26numeroProv vedimento\%3D297\%26testo\%3D\%26annoProvvedimento\%3D1994\%26giornoPr ovvedimento $\% 3$ D\&currentPage $=1$.

D.Lgs. 134/2009. Decreto Legge, 25 settembre 2009, n. 134. Gazzetta Ufficiale n. 223, 25 settembre

http://www.normattiva.it/atto/caricaDettaglioAtto?atto.dataPubblicazioneGaz zetta $=2009-09$ -

25\&atto.codiceRedazionale $=009$ G0148\&queryString $=\% 3$ FmeseProvvedimento $\%$ 3D\%26formType\%3Dricerca_semplice\%26numeroArticolo\%3D\%26numeroProv vedimento\%3D134\%26testo\%3D\%26annoProvvedimento\%3D2009\%26giornoPr ovvedimento\%3D\&currentPage $=1$.

D. Lgs 59/2017. Decreto Legislativo, 13 aprile 2017, n. 59. Gazzetta Ufficiale n. 112, 16 maggio 2017, Supplemento Ordinario n. 23. http://www.normattiva.it/atto/caricaDettaglioAtto?atto.dataPubblicazioneGaz zetta $=2017-05-$

16\&atto.codiceRedazionale $=17$ G00067\&queryString $=\% 3$ FmeseProvvedimento $\%$ 3D\%26formType\%3Dricerca_semplice\%26numeroArticolo\%3D\%26numeroProv vedimento \%3D59\%26testo \%3D\%26annoProvvedimento\%3D2017\%26giornoPro vvedimento $\% 3$ D\&currentPage $=1$.

D.M. 39/1998. Ministero dell'istruzione, dell'università e della Ricerca. Decreto $\begin{array}{llllll}\text { ministeriale } & \mathrm{n} . & 39, & 30 & \text { gennaio } & 1998 .\end{array}$ https://archivio.pubblica.istruzione.it/normativa/1998/dm039_98.pdf. 
D.M. 22/2005. Ministero dell'istruzione, dell'università e della Ricerca. Decreto $\begin{array}{llllll}\text { Ministeriale } & \text { n. } & 22, & 9 & \text { febbraio } & 2005 .\end{array}$ https://archivio.pubblica.istruzione.it/normativa/2005/dm22_05.shtml.

D.M. 37/2009. Ministero dell'istruzione, dell'università e della Ricerca. Decreto $\begin{array}{lllll}\text { Ministeriale } & \text { n. } & 37, & & \end{array}$ http:/ /2.flcgil.stgy.it/files/pdf/20090326/decreto-ministeriale-37-del-26-marzo2009-nuove-classi-di-abilitazione-e-cattedre-scuola-secondaria-di-i-grado4282831.pdf.

D.M. 249/2010. Ministero dell'istruzione, dell'università e della Ricerca. Decreto Ministeriale 10 settembre 2010, n. 249. Gazzetta Ufficiale n. 24, 31 gennaio 2011, Supplemento Ordinario n. 23. http://www.miur.it/Documenti/universita/Offerta_formativa/Formazione_in iziale_insegnanti_corsi_uni/DM_10_092010_n.249.pdf.

D.M. 11 novembre 2011. Ministero dell'istruzione, dell'università e della Ricerca. Decreto Ministeriale 11 novembre 2011. http://attiministeriali.miur.it/anno2011/novembre/dm-11112011.aspx.

D.M. 254/2012. Ministero dell'istruzione, dell'università e della Ricerca. Gazzetta $\begin{array}{llllll}\text { Ufficiale } & \mathrm{n} . & 30, & 5 & \text { maggio }\end{array}$ http://www.indicazioninazionali.it/documenti_Indicazioni_nazionali/DM_254 _201_GU.pdf.

D.M. 81/2013. Ministero dell'istruzione, dell'università e della Ricerca. Decreto Ministeriale n. 81, 25 marzo 2013. Gazzetta Ufficiale, Serie Generale, n. 155, 4 luglio 2013. http://www.gazzettaufficiale.it/eli/id/2013/07/04/13G00120/sg.

D.M. 312/2014. Ministero dell'istruzione, dell'università e della Ricerca. Decreto Ministeriale n. 312 del 16 maggio 2014. http:/ /istruzioneer.it/2014/09/29/d-mn-312-del-16-maggio-2014-di-indizione-per-lanno-accademico-2014-15-dellaselezione-per-laccesso-al-tfa-ii-ciclo-modalita-di-presentazione-delladichiarazione-di-avve/.

D.M. 850/2015. Ministero dell'istruzione, dell'università e della Ricerca. Decreto $\begin{array}{lllll}\text { Ministeriale } & \text { n. } & 850, & 27 & \text { ottobre }\end{array}$ http://www.sardegna.istruzione.it/allegati/2015/DM_850_27_10_2015.pdf.

D.M. 797/2016. Ministero dell'istruzione, dell'università e della Ricerca. Decreto Ministeriale n. 797, 19 ottobre 2016. Allegato: Piano per la Formazione dei Docenti. http://www.notiziedellascuola.it/legislazione-e-dottrina/indicecronologico/2016/ottobre/DECRETO_MIUR_20161019_797/allinone_view.

D.M. 475/2017. Ministero dell'istruzione, dell'università e della Ricerca. Decreto $\begin{array}{llllll}\text { Ministeriale } & \text { n. } & 475, & 28 & \text { giugno }\end{array}$ http:/ /3.flcgil.stgy.it/files/pdf/20170629/decreto-ministeriale-475-del-28giugno-2017-prove-di-ammissione-e-posti-disponibili-scienze-della-formazioneprimaria-2017-2018.pdf.

D.P.C.M. 25 gennaio 2008. Decreto del Presidente del Consiglio dei Ministri, 25 gennaio 2008. Gazzetta Ufficiale n. 86, 11 aprile 2008. http://www.gazzettaufficiale.it/eli/id/2008/04/11/08A02264/sg.

D.P.C.M. 28 novembre 2016. Gazzetta Ufficiale n. 281, 1 dicembre 2016. Gazzetta $\begin{array}{llllll}\text { Ufficiale } & \text { n. } & 281, & 1 & \text { dicembre } & 2016 .\end{array}$ http://www.gazzettaufficiale.it/eli/id/2016/12/1/16A08470/sg.

D.P.R. 470/1996. Decreto del Presidente della Repubblica, 27 settembre 1996. Gazzetta $\begin{array}{llllll}\text { Ufficiale } & \text { n. } & 214, & & \end{array}$ http://www.normattiva.it/atto/caricaDettaglioAtto?atto.dataPubblicazioneGaz zetta=1996-09-

12\&atto.codiceRedazionale $=096$ G0496\&queryString $=\% 3$ FmeseProvvedimento $\%$ 3D\%26formType\%3Dricerca_semplice\%26numeroArticolo\%3D\%26numeroProv 
vedimento\%3D470\%26testo\%3D\%26annoProvvedimento\%3D1996\%26giornoPr ovvedimento\%3D\&currentPage $=1$.

D.P.R. 471/1996. Decreto del Presidente della Repubblica, 31 luglio 1996, n. 471. Gazzetta $\begin{array}{lllll}\text { Ufficiale } \quad \text { n. } & 214, & 1996 .\end{array}$ http://www.normattiva.it/atto/caricaDettaglioAtto?atto.dataPubblicazioneGaz zetta=1996-09-

12\&atto.codiceRedazionale $=096$ G0497\&queryString $=\% 3$ FmeseProvvedimento $\%$ 3D\%26formType\%3Dricerca_semplice\%26numeroArticolo\%3D\%26numeroProv vedimento\%3D471\%26testo\%3D\%26annoProvvedimento\%3D1996\%26giornoPr ovvedimento \%3D\&currentPage $=1$.

D.P.R. 347/2000. Decreto del Presidente della Repubblica, 6 novembre 2000, n. 347. Gazzetta Ufficiale n. 277, del 27 novembre 2000. http://www.normattiva.it/atto/caricaDettaglioAtto?atto.dataPubblicazioneGaz zetta $=2000-11-$

27\&atto.codiceRedazionale $=000$ G0302\&queryString $=\% 3$ FmeseProvvedimento $\%$ 3D\%26formType\%3Dricerca_semplice\%26numeroArticolo\%3D\%26numeroProv vedimento \%3D347\%26testo\%3D\%26annoProvvedimento\%3D2000\%26giornoPr ovvedimento\%3D\&currentPage $=1$.

D.P.R. 260/2007. Decreto del Presidente della Repubblica, 21 dicembre 2007, n. 260. Gazzetta Ufficiale n. 18, 22 gennaio 2008. http://www.normattiva.it/atto/caricaDettaglioAtto?atto.dataPubblicazioneGaz zetta=2008-01-

22\&atto.codiceRedazionale $=008$ G0005\&queryString $=\% 3$ FmeseProvvedimento $\%$ 3D\%26formType\%3Dricerca_semplice\%26numeroArticolo\%3D\%26numeroProv vedimento\%3D260\%26testo\%3D\%26annoProvvedimento\%3D2007\%26giornoPr ovvedimento \%3D\&currentPage $=1$.

D.P.R. 17/2009. Decreto del Presidente della Repubblica n. 17, 20 gennaio 2009. Gazzetta Ufficiale $\quad n . \quad 60, \quad 13 \quad$ marzo 2009. http://www.normattiva.it/atto/caricaDettaglioAtto?atto.dataPubblicazioneGaz zetta $=2009-03-$

13\&atto.codiceRedazionale $=009$ G0025\&queryString $=\% 3$ FmeseProvvedimento $\%$ 3D\%26formType\%3Dricerca_semplice\%26numeroArticolo\%3D\%26numeroProv vedimento\%3D17\%26testo\%3D\%26annoProvvedimento\%3D2009\%26giornoPro vvedimento\%3D\&currentPage=1.

D.P.R. 81/2009. Decreto del Presidente della Repubblica, 20 marzo 2009, n. 81. Gazzetta $\begin{array}{llllll}\text { Ufficiale } & \text { n. } & 151, & 2 & \text { luglio } & 2009 .\end{array}$ http://www.normattiva.it/atto/caricaDettaglioAtto?atto.dataPubblicazioneGaz zetta=2009-07-

02\&atto.codiceRedazionale $=009$ G0089\&queryString $=\% 3$ FmeseProvvedimento $\%$ 3D\%26formType\%3Dricerca_semplice\%26numeroArticolo\%3D\%26numeroProv vedimento\%3D81\%26testo \%3D\%26annoProvvedimento\%3D2009\%26giornoPro vvedimento\%3D\&currentPage $=1$.

D.P.R. 89/2010. Decreto del Presidente della Repubblica, 15 marzo 2010, n. 89. Gazzetta Ufficiale n. 137, 15 maggio 2010, Supplemento Ordinario, n. 128. http://www.normattiva.it/atto/caricaDettaglioAtto?atto.dataPubblicazioneGaz zetta $=2010-06-$

15\&atto.codiceRedazionale $=010$ G0111\&queryString $=\% 3$ FmeseProvvedimento $\%$ 3D\%26formType\%3Dricerca_semplice\%26numeroArticolo\%3D\%26numeroProv vedimento\%3D89\%26testo\%3D\%26annoProvvedimento\%3D2010\%26giornoPro vvedimento \%3D\&currentPage $=1$.

L. 341/1990. Legge 19 novembre 1990, n. 341. Gazzetta Ufficiale n. 274, 23 novembre 1990.

http://www.normattiva.it/atto/caricaDettaglioAtto?atto.dataPubblicazioneGaz 
zetta=1990-11-

23\&atto.codiceRedazionale=090G0387\&queryString $=\% 3$ FmeseProvvedimento $\%$ 3D\%26formType\%3Dricerca_semplice\%26numeroArticolo\%3D\%26numeroProv vedimento\%3D341\%26testo\%3D\%26annoProvvedimento\%3D1990\%26giornoPr ovvedimento \%3D\&currentPage $=1$.

L. 104/1992. Legge 5 febbraio 1992, n. 104. Gazzetta Ufficiale n. 39, del 17 febbraio 1992, Supplemento Ordinario $n$. 30 http://www.normattiva.it/atto/caricaDettaglioAtto?atto.dataPubblicazioneGaz zetta=1992-02-

17\&atto.codiceRedazionale $=092$ G0108\&queryString $=\% 3$ FmeseProvvedimento $\%$ 3D\%26formType\%3Dricerca_semplice\%26numeroArticolo\%3D\%26numeroProv vedimento\%3D104\%26testo\%3D\%26annoProvvedimento\%3D1992\%26giornoPr ovvedimento $\% 3 \mathrm{D} \&$ currentPage $=1$.

L. 124/1999. Legge, 3 maggio 1999, n. 124. Gazzetta Ufficiale n. 107, 10 maggio 1999. http://www.normattiva.it/atto/caricaDettaglioAtto?atto.dataPubblicazioneGaz zetta=1999-05-

10\&atto.codiceRedazionale $=099$ G0205\&queryString $=\% 3$ FmeseProvvedimento $\%$ 3D\%26formType\%3Dricerca_semplice\%26numeroArticolo\%3D\%26numeroProv vedimento\%3D124\%26testo\%3D\%26giornoProvvedimento\%3D\%26annoProvve dimento\%3D1999\&currentPage $=1$.

L. 296/2006. Legge, 27 dicembre 2006, n. 296. Gazzetta Ufficiale n. 299, 27 dicembre 2006, Supplemento Ordinario n. 244.

L. 240/2010. Legge 30 dicembre 2010, n. 240. Gazzetta Ufficiale n. 10, del 14 gennaio 2011, Supplemento Ordinario n. 11.

L. 107/2015. Legge, 13 luglio 2015, n. 107. Gazzetta Ufficiale n. 162, 15 luglio 2015. http://www.normattiva.it/atto/

Ministero dell'Istruzione, dell'Università e della Ricerca (MIUR) (2017), La Buona Scuola. I decreti attuativi. Schede di approfondimento[The Good School. Implementing decrees.

http://www.istruzione.it/allegati/2017/La_Buona_Scuola_Approfondimenti.p df.

Ministero dell'istruzione, dell'Università e della Ricerca (MIUR), Piano per la formazione in servizio dei docenti 2016-2019 [Plan for in-service training of teachers 20162019]. http://www.istruzione.it/piano_docenti.

Ministero dell'Istruzione, dell'Università e della Ricerca (MIUR), Ufficio Relazioni con il Pubblico, (2012). Organi collegiali della scuola [Schools' Collegial Bodies]. Retrieved from: http://www.istruzione.it/urp/organi_collegiali.shtml.

Savelli, S. (2014a). Education and training in Italy: Status and transitions. Education Journal, 3(6), 323-339. https:// doi.org/10.11648/j.edu.20140306.12.

Savelli, S. (2014b). Italian Lifelong Learning in Europe: Notes to the Second Millennium. Journal of Education and Training Studies, 2(2), 87-104. Redfame Publishing Inc. https://doi.org/10.11114/jets.v2i2.303.

Savelli, S. (2015). Istruzione e formazione nel secondo millennio: gli Stati Uniti [Education and training in the second millennium: the United States]. Orientamenti Pedagogici, 62(4), 873-889. Erickson. http://rivistedigitali.erickson.it/orientamenti-pedagogici/archivio/vol-62-n-4/.

Savelli, S. (2016), Istruzione e formazione nel secondo millennio: la formazione professionale dell'insegnante negli Stati Uniti [Education and training in the second millennium: teacher training in the United States]. Orientamenti Pedagogici, 63(2), 383-408. Erickson. http://rivistedigitali.erickson.it/orientamenti-pedagogici/archivio/vol-63-n-2$5 /$. 